\title{
3.3 Udal musika eskola bateko dantza jarduera erorikoen prebentziorako: adinekoei zuzendutako esku-hartzea.
}

\author{
Maialen Araolaza Arrieta \\ EHUko Fisioterapia irakaslea \\ maraolaza@gmail.com
}

\section{Sarrera}

Erorikoak epe luzeko komorbilitatearekin lotzen dira eta adineko pertsonen funtzionaltasuna kaltetzen dute. Urtero, komunitatean bizi diren hiru pertsona adinduetatik bat erori egiten da. Nolanahi ere, biztanleriaren zahartzea erronka garrantzitsua izanik, esku hartze prebentibo eraginkorrek aukera ematen dute erorikoek eragindako ondorio pertsonal, sozial eta ekonomiko handiak ekiditeko.

Ariketa fisikoa oinarri, taldean gauzatutako esku hartzeak eraginkorrak dira erorikoen prebentziorako (Gillespie et al., 2012), batez ere oreka lantzen badute (Sherrington et al., 2016). Halere, adinekoei zuzendutako esku hartze horien atxikimendu tasak baxuak izan ohi dira, eta eraginkortasuna kolokan jartzen dute. Hori dela eta, esku hartzeek sortzen duten gozamena eta gogobetetzea garrantzitsuak izan daitezke epe luzeko atxikimendua lortzeko (Kendall \& Fairman, 2014).

Dantzak mugimendua, zentzumenak eta funtzio kognitiboa sustatzen ditu (Kattenstroth et al., 2010) eta etorkizun handiko esku hartzea da, adinarekin batera gaitasun fisiko eta mentalek jasaten duten gainbeherari aurre egiteko (Rehfeld et al., 2017). Dantzaren onurak hobeto zehazteko ausazko azterketa kontrolatu gehiago behar diren arren, gomendatzen da adinekoei zuzendutako eta dantzan oinarritutako programen parte hartzean eta atxikimenduan eragiten duten faktoreei buruz ikertzea (Keogh et al., 2009). Izan ere, epe luzeko atxikimendua lortuz gero, erorikoak saihesteko esku hartze eraginkortzat har liteke dantza.

Lan honen helburua da adinekoek parte hartze eta atxikimendu handia erakutsi duten euskal dantza tradizionaleko (DT) programa baten ezaugarriak deskribatzea, erorikoen prebentzioaren ikuspegitik.

\section{Metodologia}

Bilboko "BilbaoMusika" DTko eskola ezagun baten ezaugarriak aztertu ziren, bereziki atxikimenduarekin eta motibazioarekin zerikusia zutenak (hala nola programa bera, irakaskuntzametodologia eta partaideen ezaugarriak), egindako erregistro instituzionaleko eta entsegu aleatorio kontrolatuko datuetan oinarrituta.

\section{Emaitzak}

\subsection{Iraupena eta dosia}


DT programak 6 urteko iraupena zuen eta maila bakoitzak, ikasturte batekoa. Astean bi saio ematen ziren (150 min astean): 90 minutuko eskolaldia (eskolan egiten zen, eduki berriak ikasteko), eta 60 minutuko praktikaldia (eskolatik kanpo egiten zen, eskolaldiko edukiak birpasatzeko).

\subsection{Irakaslea eta metodologia}

Dantzako irakasle aditu batek gidatzen zituen eskolak, musikan prestakuntza ere bazuena. Programaren zailtasun progresiboak hauek izan ziren: 1) musikak ezarritakoa, 2) urratsa eta mugimendua bera eta 3) espazioaren erabilera (1). Lehen lau urteetan, 15 dantza multzotik gora ikasi ziren, eta, ikasi ahala, haien aldaerak landu ziren errepaso gisa. Saioak 7-9 minutuko ataletan zeuden antolatuta, hainbat helburu eta metodologia txandakatuz. Ikasteko metodologiaren arabera, zenbait baliabide erabili ziren: erritmoak eskuekin edo hitzekin lantzea, tempoaren aldaketa, rol aldaketa, etab. DT saioen bidez gizarte-interakzioa, plazera eta komunitatearekiko identifikazioa (erantsitako balore kulturala barne) sustatu ziren.

1. irudia. DT programaren zailtasun progresiboak. Adibide bat: Baztango zortzikoa.

1) Musikak ezarritakoa

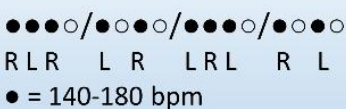

R L

$\bullet=140-180 \mathrm{bpm}$
2) Urratsa eta mugimendua

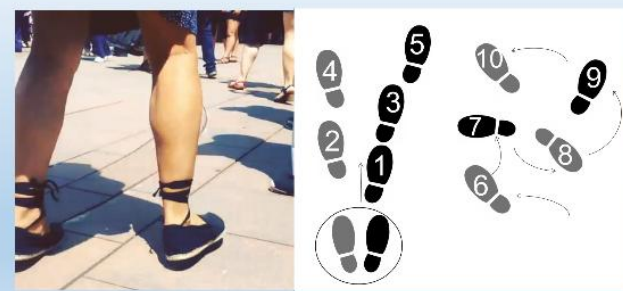

3) Espazioaren erabilera

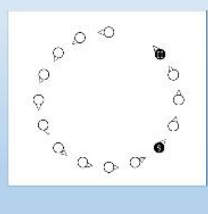

\subsection{Parte-hartzaileak}

Erregistro instituzionalari dagokionez, ikasturtea hasi baino lehen izena emanda zuten 331 partehartzaileen \% 47k (\%83 emakumeak ziren) 60 urte baino gehiago zituen. Eskaintzen zen plaza kopurua baino izen emate gehiago egon ziren (\% 64 itxarote-zerrendan gelditu zen), eta \%9k jarduera utzi egin zuen. Urteko matrikula 68,6 eurokoa izan zen.

Entsegu aleatorio kontrolatuari dagokionez, aldiz, 60 urte baino gehiago izan eta entseguan parte hartzea onartu zuten emakumeen artean $(n=22) \% 90$ bertaratu zen saioetara. \% 15ak joateari utzi egin zion, honako arrazoi hauengatik: osasun arazoak (\% 4), lanarekin kontziliazio zailtasunak (\% 4), eta ikerketan parte hartzea errefusatu izana (\% 7).

\section{Ondorioak}

DT programa epe luzerako talde jarduera erakargarri bat da, gaitasun sentsoriomotorrak eta kognitiboak sustatu eta erorikoak prebenitzeko gomendio asko betetzen dituena. Jardueraren berezko ezaugarriez gain, beste faktore batzuk, hala nola sozialak, psikologikoak eta demografikoak (inklusibitatea), kulturalak (identitatea) eta irisgarritasunak (osasun orokorra, ekonomia), garrantzitsuak izan daitezke adineko pertsonen erakarpena, atxikimendua eta motibazioa lortzeko. Esku hartze eredu honen ezaugarriak, beraz, beste ingurune batzuetan imitatu ahal izango dira. 
1. Gillespie, L. D., Robertson, M. C., Gillespie, W. J., Sherrington, C., Gates, S., Clemson, L. M., \& Lamb, S. E. (2012). Interventions for preventing falls in older people living in the community. The Cochrane Database of Systematic Reviews, 9, CD007146. https://doi.org/10.1002/14651858.CD007146.pub3

2. Kattenstroth, J.-C., Kolankowska, I., Kalisch, T., \& Dinse, H. R. (2010). Superior Sensory, Motor, and Cognitive Performance in Elderly Individuals with Multi-Year Dancing Activities. Frontiers in Aging Neuroscience, 2. https://doi.org/10.3389/fnagi.2010.00031

3. Kendall, K. L., \& Fairman, C. M. (2014). Women and exercise in aging. Journal of Sport and Health Science, 3(3), 170-178. https://doi.org/10.1016/j.jshs.2014.02.001

4. Keogh, J. W. L., Kilding, A., Pidgeon, P., Ashley, L., \& Gillis, D. (2009). Physical benefits of dancing for healthy older adults: a review. Journal of Aging and Physical Activity, 17(4), 479500.

5. Rehfeld, K., Müller, P., Aye, N., Schmicker, M., Dordevic, M., Kaufmann, J., Hökelmann, A., \& Müller, N. G. (2017). Dancing or Fitness Sport? The Effects of Two Training Programs on Hippocampal Plasticity and Balance Abilities in Healthy Seniors. Frontiers in Human Neuroscience, 11. https://doi.org/10.3389/fnhum.2017.00305

6. Sherrington, C., Tiedemann, A., Fairhall, N. J., Hopewell, S., Michaleff, Z. A., Howard, K., Clemson, L., \& Lamb, S. E. (2016). Exercise for preventing falls in older people living in the community. In The Cochrane Library. John Wiley \& Sons, Ltd. https://doi.org/10.1002/14651858.CD012424 